\title{
RELACIÓN ENTRE SABERES CAMPESINOS Y VARIABLES CLIMÁTICAS EN LA REGIÓN CENTRO ORIENTE DE PUEBLA, MÉXICO
}

\author{
RELATIONSHIP BETWEEN PEASANT KNOWLEDGE AND CLIMATE VARIABLES IN THE \\ CENTRAL-EASTERN REGION OF PUEBLA, MÉXICO
}

\author{
Ma. de los Ángeles Velasco-Hernández ${ }^{1}$, Tomás Morales-Acoltzi ${ }^{2}$, J. Pedro Juárez-Sánchez ${ }^{3^{*}}$, \\ N. Gabriel Estrella Chulim ${ }^{3}$, Ramón Díaz-Ruíz ${ }^{3}$, Rogelio Bernal-Morales ${ }^{4}$
}

\begin{abstract}
${ }^{1}$ Facultad de Ingeniería Química, BUAP. Ciudad Universitaria. Avenida San Claudio y 18 sur, 72570. Puebla, México. (ambientalbuap@yahoo.com.mx). ${ }^{2}$ Modelación Matemática de Procesos Atmosféricos, Centro de Ciencias de la Atmósfera, UNAM, México, D.F. 04510, (acoltzi@ atmosfera.unam.mx). ${ }^{3}$ Colegio de Postgraduados, Campus Puebla, Carretera Federal México-Puebla km 125.5, Santiago Momoxpan, municipio de San Pedro Cholula, Puebla. 72760. (pjuarez@colpos. mx, nestrela@colpos.mx, dramon@colpos.mx). ${ }^{4}$ Centro de Investigación en Cambio Climático, Facultad de Agrobiología, UATx,, Campus Tlaxco, Tlaxcala. (rbernal07@hotmail.com)
\end{abstract}

\section{RESUMEN}

La agricultura y especialmente el cultivo del maíz representan una de las actividades socioeconómicas más importantes para la seguridad alimentaria en México. A través del tiempo, el conocimiento empírico ha sido trasmitido de generación en generación. En esta investigación se aplicaron encuestas a agricultores en la región Centro Oriente del estado de Puebla, con experiencia en la siembra del maíz en 2014 y 2015. El objetivo de la investigación fue explicar la relación del climatemperatura y precipitación-, a escala pentadal, con los refranes y con los rendimientos en los ańos de 1980, 1987, 2011 y 2013. Los resultados mostraron que menos de la mitad de los agricultores confían en los dichos y, como consecuencia, en ańos con buenos rendimientos en el cultivo de maíz, la mayoría de estos fueron validados, mientras que para aquellos considerados como "regular" y "malo", la mayor parte no se cumplió. Estas dos situaciones se pueden explicar en términos de una visión optimista del agricultor. Se concluye que el conocimiento empírico campesino sobre el pronóstico tiempo/clima es aceptado por una parte importante de agricultores y sigue influyendo en las actividades agrícolas.

Palabras clave: agricultura, conocimiento empírico, precipitación, temperatura

* Autor responsable * Author for correspondence. Recibido: diciembre, 2015. Aprobado: febrero, 2016. Publicado como ARTÍCULO en ASyD 13: 643-662. 2016.

\section{AbStract}

Agriculture and especially maize cultivation represent one of the most important socioeconomic activities for food security in México. Throughout time, empirical knowledge has been transmitted from generation to generation. In the study, surveys were applied to farmers in the Central-Eastern region of the state of Puebla, with experience in sowing maize, during 2014 and 2015. The objective of the research was to explain the relationship between climate-temperature and precipitation-, at pentad scale, with the proverbs and yields of the years 1980, 1987, 2011 and 2013. Results showed that at least half of the farmers trust in the sayings and, as consequence, in years with good yields of the maize crop, most of them were validated, while for those considered as "regular" and "bad", most did not come true. These two situations can be explained in terms of an optimistic vision of the farmer. It is concluded that peasant empirical knowledge about time/weather prediction is accepted by an important number of farmers and continues to influence agricultural activities.

Key words: agriculture, empirical knowledge, precipitation, temperature.

\section{INTRODUCTION}

$\mathrm{T}$ The sayings, sapiensas or proverbs date from ancient times; they are constituted into a form of popular knowledge, based on repeated observations by multiple people throughout many years, and they are the result of the existence of collective memory; they are considered wise men's 


\section{INTRODUCCIÓN}

L os dichos, sapiensas o refranes datan de la época antigua; se constituyen en una forma de sabiduría popular, basada en observaciones repetidas por múltiples personas a lo largo de muchos años, y son el resultado de la existencia de una memoria colectiva; eran considerados dichos de sabios a propósito de los cuales no se podían discutir y ninguno era tan sabio que pudiera acertar tanto como el pueblo. Así, los refranes se tenían como principio y no había necesidad de explicarlos, pero debería tenerse alguna observación, no en cuanto al valor intrínseco sino a su utilización, en la cual exigían cierta mesura (Gallego, 2011). Entonces, los refranes son enunciados fraseológicos emanados de la síntesis de la sabiduría popular y son fuente de conocimiento que ayuda a entender la realidad cotidiana; además de enriquecer el idioma reflejan las prácticas de la cultura de un pueblo (González, 2015). Se basan en la observación de la naturaleza y el conocimiento que se ha traducido en frases, proverbios y dichos, y en nuestros días tienen importancia fundamentalmente entre la población rural.

De acuerdo con Sevilla y Crida (2013), en la actualidad se definen como "una paremia de origen anónimo y uso popular cuya estructura es generalmente bimembre, con presencia de elementos mnemotécnicos, con potencial presencia de elementos jocosos, basado en la experiencia y con valor de verdad universal, en su gran mayoría"; y los clasifican en refranes temporales y meteorológicos, lo que significa que en el conocimiento tradicional los proverbios se han aplicado en la previsión meteorológica que representan factores que son cruciales para los agricultores. En Europa se cuenta con una Base de Datos Sobre Refranes del Calendario y Meteorológicos en la Romania (BADARE); en ella se muestra la riqueza del saber patrimonial, compartido en torno a la meteorología popular por los pueblos románicos del viejo continente. Por ejemplo, San Cristóbal con gorro, agua hasta el morro (Monte cercano a Pamplona) (Gargallo et al., 2008). Los proverbios utilizados en la región de Sinazongwe, Zambia se aplican como predictores meteorológicos, aunque en ciertos casos es difícil predecir la lluvia en tierras con diferente pendiente; las bases de datos que se utilizan son primordiales para estimar el potencial local del clima, que está relacionado con futuros cambios climáticos (Kanno et al., 2013). sayings about which they could not argue and none was so wise as to being right as often as the people. Thus, the sayings were there as principle and there was no need to explain them, but there had to be some observation, not in terms of the intrinsic value but rather its use, in which they demanded certain restraint (Gallego, 2011). Then, the proverbs are phraseological statements emanated from the synthesis of popular wisdom and they are source of knowledge that helps to understand daily reality; in addition to enrichening the language they reflect the practices of the culture of a people (González, 2015). They are based on the observation of nature and the knowledge that has been translated into phrases, proverbs and sayings, and in our days they are important fundamentally among the rural population.

According to Sevilla and Crida (2013), currently they are defined as "a saying of anonymous origin and popular use whose structure is generally in two parts, with presence of mnemonic elements, with potential presence of funny elements, based on experience and with value of universal truth, in their majority"; and they classify them into temporal and meteorological proverbs, which means that in the traditional knowledge the proverbs have been applied in the meteorological forecast that represent factors which are crucial to farmers. In Europe, there is a Database about Calendar and Meteorological Proverbs in the Romania (Base de Datos Sobre Refranes del Calendario $y$ Meteorológicos en la Romania, BADARE); in it the wealth of the patrimonial knowledge, shared around popular meteorology by the romance peoples of the old continent, is shown. For example, Saint Cristopher with a hat, or water up to the bluff (mountain near Pamplona) (Gargallo et al., 2008). The proverbs used in the region of Sinazongwe, Zambia, are applied as meteorological predictors, although in certain cases rainfall is difficult to predict in lands with different slopes; the databases that are used are primordial to estimate the local potential of climate, which is related to future climate changes (Kanno et al., 2013).

In Pre-Hispanic México of the $7^{\text {th }}$ to $14^{\text {th }}$ Centuries, the deity Tláloc had a prominent place; thanks to him the land could be kept fertile and men could live; they symbolized God representing him with rings around the eyes, similar to glasses that simulated the clouds (De Pedraza, 2014). In the 
En el México precolombino de los siglos VII al XIV el Dios Tláloc tenía un lugar destacado; gracias a él podía mantenerse fecunda la tierra y los hombres podían vivir; simbolizaban al Dios, representándolo con unos anillos alrededor de los ojos, semejante a unas gafas que simulaban las nubes (De Pedraza, 2014). En la Sierra Purépecha lograron relacionar los aspectos físicos con la percepción de cambios en el periodo de lluvias, las bajas temperaturas y las granizadas que para una agricultura de temporal es crucial; además, consideraron la diferenciación espacial de temperatura, la pendiente, fertilidad del suelo, y la situación socioeconómica comunitaria y extracomunitaria (Magaña, 2008).

Oliviusson (2010) considera que la utilidad de los refranes es transmitir mensajes de tipo moral con la intención de criticar a la sociedad en la que se han institucionalizado. Bajo el enfoque "tradicional" existen refranes que ayudan a salir airosos de situaciones difíciles, donde cualquier aspecto de la vida humana se ve reflejado en ellos y su campo de aplicación presenta una gran variedad dada su amplitud temática, por estar circunscritos a una zona geográfica, a un ámbito concreto, ya sea laboral o social (Sevilla y Cantera, 2002). Entonces, se puede decir que los refranes hacen referencia a contextos locales y no universales, y abarcan periodos de corto y largo plazo. Lo cierto es que estamos frente al saber popular y el conocimiento científico.

En los saberes campesinos, González (2008) menciona que se originaron por la acumulación de experiencias, conocimientos, creencias y costumbres que son consistentes entre sí, donde los saberes son el conocimiento empírico de los campesinos. El estudio formal de los sistemas de conocimiento tradicional ha llevado a entender que se trata de sistemas cognitivos conformados por una praxis y un corpus interdependientes entre sí, donde el corpus no es sino la suma y el repertorio de signos, símbolos, conceptos y percepciones de lo que se considera el sistema cognitivo tradicional (Torres y Valdivia, 2012). Aquí destaca la cosmovisión campesina que, de acuerdo con Juárez (2010), parte de la observación sistemática de la naturaleza, donde las contemplaciones y reflexiones en torno a ella eran comprobadas día a día, lo que les permitió clasificar, pronosticar y formular conocimientos que integran a las comunidades en su forma de vida.

Mesa et al. (1997) mencionan que la meteorología popular ha facilitado a la gente del campo un
Sierra Purépecha they managed to relate the physical aspects with the perception of changes in the rainy period, low temperatures and hail storms which are crucial for rainfed agriculture; in addition, they considered the spatial differentiation of temperature, slope, soil fertility, and the socioeconomic situation inside and outside the community (Magaña, 2008).

Oliviusson (2010) considers that the use of proverbs is to transmit messages of moral type with the intention of criticizing the society in which they have become institutionalized. Under the "traditional" approach there are sayings that help them to overcome difficult situations, where any aspect of human life is reflected in them and their application field presents a large variety given its thematic range, because they are circumscribed to a geographic zone, to a concrete scope, whether labor or social (Sevilla and Cantera, 2002). Then, it can be said that the proverbs refer to local contexts and not universal ones, and that they cover periods in the short and long term. What is true is that we are dealing with popular knowledge and scientific knowledge.

In peasant knowledge, González (2008) mentions that they originated from the accumulation of experiences, knowledge, beliefs and customs that are consistent between each other, where the understandings are the empirical knowledge of peasants. The formal study of traditional knowledge systems has allowed understanding that there are cognitive systems made up of praxis and corpus that are interdependent, where the corpus is nothing but the sum and repertoire of signs, symbols, concepts and perceptions of what is considered the traditional cognitive system (Torres and Valdivia, 2012). The peasant worldview stands out here, which, according to Juárez (2010), stems from the systematic observation of nature, where contemplation and reflections around it were tested day to day, allowing them to classify, forecast and formulate knowledge that make up the communities in their lifestyles.

Mesa et al. (1997) mention that popular meteorology has made available to country people a general and open scheme to program agricultural tasks, constituting the Collection of Proverbs into a fundamental deposit of popular meteorological knowledge. This is why most of the proverbs about time have their origin in the rural environment and frequently link meteorology and agriculture, allowing 
esquema general y abierto para programar tareas agrícolas, constituyéndose el Refranero en un depósito fundamental del saber meteorológico popular. Es por ello que la mayor parte de los refranes sobre el tiempo tienen su origen en el medio rural y con frecuencia vinculan meteorología y agricultura, permitiéndolo enfocar desde una perspectiva multidisciplinar, integrando contenidos geográficos, lingüísticos, históricos, antropológicos, etcétera, desarrollando estrategias de enseñanza-aprendizaje basadas en la indagación y la investigación empírica (Gaite, 2011) donde los conocimientos de los campesinos han sido guardados y sistematizados mediante indicadores climáticos en su cultura, la cual tiene como finalidad práctica prevenir lo que puede suceder con las características del clima y sus efectos en la época de cultivos (Claverías, 2000).

Los refranes que hacen referencia al clima aluden a tres parámetros: temperaturas, precipitaciones y régimen de vientos. Su estudio se complementa con el análisis de la influencia que éste ejerce sobre las actividades humanas y específicamente en la agricultura. Es por ello que algunos refranes se refieren al clima -las temperaturas y precipitaciones- y otros que relacionan el tiempo atmosférico y la agricultura (Marrón, 2011). Es por ello que la observación del cielo ha sido una preocupación del hombre para conocer la influencia de los astros en los ciclos vegetativos. Esta práctica desarrolló el conocimiento del saber popular que ha permitido pronosticar el tiempo climático en determinados días del año. Aquí las previsiones se hacen a corto plazo para las horas o los días siguientes, y a largo plazo para la llegada del temporal y para todo el año (Blanc y Blanc, 2003). Es el caso de los denominados tiemperos que, de acuerdo con Juárez (2010), se basan en ciertos elementos de la naturaleza para pronosticar el temporal. Entonces se puede hablar del desarrollo del conocimiento tradicional sobre su territorio, expresándose en la capacidad de minimizar riesgos, en una producción eficaz derivada de la mezcla de cultivos, la restauración de la fertilidad del suelo mediante rotación con leguminosas (Altieri y Nicholls, 2000).

Con respecto a la objetividad de los refranes, existen estudiosos que mencionan que sería reduccionista pensar que los refranes meteorológicos son simplemente un manual fragmentario de métodos precientíficos para la predicción del tiempo, ya que los refranes meteorológicos constituyen pequeños tratados que them to focus from a multidisciplinary perspective, integrating geographic, linguistic, historical, anthropological, etc., contents, developing teachinglearning strategies based on inquiry and empirical research (Gaite, 2011), where the knowledge of peasants has been saved and systematized through climatic indicators in their culture, which has the practical finality of preventing what can happen with climate characteristics and their effects on the farming season (Claverías, 2000).

The sayings that refer to the climate allude to three parameters: temperature, precipitation and wind regime. Their study is complemented with the analysis of the influence that it exerts on human activities and specifically on agriculture. This is why some proverbs refer to the climate-temperatures and precipitation - and others relate atmospheric time and agriculture (Marrón, 2011). This is why observing the sky has been a preoccupation of man to understand the influence of celestial bodies on vegetative cycles. This practice developed the understanding of popular knowledge that has allowed forecasting climate time in specific days of the year. Here the previsions are made in the short term for the next hours or days, and in the long term for the arrival of the rain season and for the whole year (Blanc and Blanc, 2003). It is the case of the so-called tiemperos, who, according to Juárez (2010), are based on certain elements of nature to forecast the rain season. Then there can be talk of the development of traditional knowledge about their territory, expressed in the capacity to minimize risks, in an efficient production derived from the mixture of crops, the restoration of soil fertility through rotation with pulses (Altieri and Nicholls, 2000).

With regards to the objectivity of the proverbs, there are scholars who mention that it would be reductionist to think that the meteorological proverbs are simply a fragmentary manual of pre-scientific methods for climate prediction, since meteorological sayings constitute small treaties that synthesize popular knowledge accumulated during centuries through the empirical observation of time, in an easy and simple way for their communication, without the need to adopt technical language or for the receiver to have specialized knowledge (Álvarez, 2013). In this sense there are three types of meteorological sayings according to their veracity: those that are not true, since there is some superstition, and which 
sintetizan la sabiduría popular acumulada en siglos mediante la observación empírica del tiempo, de un modo fácil y sencillo para su difusión, sin necesidad de adoptar un lenguaje técnico ni de que el receptor posea un conocimiento especializado (Álvarez, 2013). En ese sentido hay tres tipos de refranes meteorológicos de acuerdo con su veracidad: los que no son verdaderos, ya que existe algo de superstición, y que han permanecido entre los habitantes por su antigüedad y la rima que tienen; los que están desplazados de su entorno de actuación conforman el grupo de refranes meteorológicos; y los refranes verdaderos, que se basan generalmente en la observación directa del fenómeno y su veracidad está confirmada por la meteorología (Conde, 1998).

De acuerdo con Fernández de Arróyabe (1999), en este tipo de refranes su objetividad y el valor de la experiencia dependen, entre otros aspectos, de la fiabilidad de la memoria. También menciona que en ocasiones las coincidencias entre la realidad física y el conocimiento popular se encuentran separadas por errores de percepción y se establecen tópicos no ajustados a la realidad meteorológica y climática que solo pueden ser resueltos desde la óptica científica. Además, Álvarez (2013) comenta que se debe tener en cuenta que los refranes de este tipo informan sobre el comportamiento meteorológico en zonas concretas, con un microclima particular que puede variar de un espacio a otro porque su morfología, la dinámica de los vientos, el tipo de terreno, entre otros, son diferentes. También tiene que tomarse en cuenta el paso del tiempo, -ya que dice que hasta el refranero sufre transformaciones en el tiempo-, y el cambio de costumbres que hacen que se comience a cuestionar su verdad (Conde, 1998).

Por su parte, Rodríguez et al. (2004) comentan que la veracidad o falsedad de los refranes meteorológicos no es intrínseca y viene dada por el aspecto fundamental de la ciencia meteorológica: la localización, que cuanto más precisa sea, más posibilidad hay de que pueda comprobarse. En la actualidad, la predicción meteorológica puede realizarse mediante técnicas estadísticas; la más usual, y que ofrece mejores resultados, se basa en la resolución a través de ecuaciones matemáticas correspondientes a las leyes físicas que describen el comportamiento de la atmósfera. A pesar de que las técnicas de predicción meteorológica han evolucionado, en ocasiones se cometen errores debido a que los modelos fallan o porque el have remained among the inhabitants because of their antiquity and the rhyme they have; those that are displaced from their scope of action, which make up the group of meteorological sayings; and the true proverbs, which are based generally on the direct observation of the phenomenon and whose veracity is confirmed by meteorology (Conde, 1998).

According to Fernández de Arróyabe (1999), in this type of proverbs their objectivity and the value of experience depend, among other aspects, on the reliability of memory. He also mentions that on occasions the coincidences between the physical reality and popular knowledge are separated by errors of perception and topics are established that are not adjusted to the meteorological and climatic reality which can only be solved from the scientific point of view. In addition, Álvarez (2013) mentions that it must be taken into account that sayings of this type inform about the meteorological behavior in concrete zones, with a particular microclimate that can vary from one space to another because the morphology, the wind dynamics, the type of terrain, among others, are different. The passing of time also needs to be taken into account - since it is said that even the collection of sayings suffers transformations over time - and the change in customs, which cause their veracity to begin to be questioned (Conde, 1998).

In their turn, Rodríguez et al. (2004) mention that the veracity or falsehood of the meteorological proverbs is not intrinsic and it is determined by the fundamental aspect of meteorological science: the location, which the more precise it is the greater the possibility of being proven. Currently, meteorological prediction can be performed through statistical techniques; the most usual, and which offers best results, is based on the solution through mathematical equations that correspond to physical laws which describe the behavior of the atmosphere. Although the meteorological prediction techniques have evolved, on occasions mistakes are made because the models fail or because the meteorologist does not interpret well the model's results (meteorological maps) (Rodríguez et al., 2004).

It can be said that the accumulation of knowledge in the proverbs was based on observation, highlighting that of the skies, the moon, and the cabañuelas; however, in face of climate change, the method that is closest is the interpretation of the moon (Blanc 
meteorólogo no interpreta bien los resultados (mapas meteorológicos) del modelo (Rodríguez et al., 2004).

Se puede decir que la acumulación de conocimientos en los refranes se basó en la observación, destacando la realizada a los cielos, la luna y las cabañuelas; sin embargo, ante el cambio climático, el método que más se aproxima es la interpretación de la luna (Blanc y Blanc, 2003), es por ello que en la actualidad los saberes campesinos son considerados inadecuados, incluso atrasados, pero también reconocidos como apropiados y revolucionados con problemas específicos de limitaciones ambientales (Knight, 1980). Dentro del contexto del conocimiento tradicional, las respuestas locales a las nuevas experiencias del cambio climático están siendo incorporadas a las percepciones endógenas de una manera selectiva, fragmentada, y modificada, pero pueden constituir un importante enfoque práctico para hacer frente a dichos cambios e incluso articularlos con las políticas de desarrollo local para enfrentar los riesgos e identificar los problemas de vulnerabilidad a escala local y regional (Molina, 2014).

Ante esta nueva corriente, Rúa (2013) menciona que, aunque carentes de la precisión científica, acumulan la sabiduría colectiva basada en la experiencia de cientos de generaciones y que, a pesar que algunos pueden estar basados en supersticiones o creencias, otros provienen del antiguo empirismo y algunas de las aseveraciones meteorológicas que incluso no han cambiado en nuestros días, por lo que varios meteorólogos oficiales han salido en defensa de estas verdades contenidas en los refranes meteorológicos. El objetivo de la investigación fue explicar la relación de la distribución anual de la lluvia a escala pentadal con los refranes y rendimientos de dos ańos "buenos", 1980 y 2013; un año "regular", 1987; y uno "malo" 2011, en dos municipios del centro oriente de Puebla.

\section{Características generales de los municipios de estudio y metodología}

La investigación se realizó en los municipios de Chalchicomula de Sesma y Tlachichuca (Figura 1). El primer municipio se encuentra entre los paralelos $18^{\circ} 52^{\prime}$ y $19^{\circ} 05^{\prime}$ de latitud norte y los meridianos $97^{\circ} 16^{\prime}$ y $97^{\circ} 34^{\prime}$ de longitud oeste; el segundo se ubica entre los paralelos $19^{\circ} 02^{\prime}$ y $19^{\circ} 16^{\prime}$ de latitud norte y los meridianos $97^{\circ} 12^{\prime}$ y $97^{\circ} 30^{\prime}$ de longitud oeste. El uso de suelo destinado a la agricultura and Blanc, 2003), which is why currently the peasant understandings are considered inadequate, even backwards, but are also recognized as appropriate and revolutionized with specific problems of environmental limitations (Knight, 1980). Within the context of traditional knowledge, the local answers to the new experiences of climate change are being incorporated into the endogenous perceptions in a selective, fragmented and modified manner, but they can constitute an important practical approach to face such changes and even articulate them with the policies of local development to face the risks and identify the problems of vulnerability at the local and regional scale (Molina, 2014).

In face of this new current, Rúa (2013) mentions that they accumulate collective knowledge based on the experience of hundreds of generations even if lacking scientific precision, and that many official meteorologists have come to defend these truths contained in the meteorological proverbs, despite some possibly being based on superstitions or beliefs, others stemming from ancient empiricism and some meteorological assertions having not even changed in our days. The objective of the research was to explain the relationship of the annual distribution of rain at the pentad scale with the proverbs and yields of two "good" years, 1980 and 2013; a "regular" year, 1987; and a "bad" one, 2011 , in two municipalities of the central-eastern region of Puebla.

\section{General characteristics of the municipalities of study and methodology}

The study was carried out in the municipalities of Chalchicomula de Sesma and Tlachichuca (Figure 1). The first municipality is located between parallels $18^{\circ} 52^{\prime}$ and $19^{\circ} 05^{\prime}$ of latitude north and meridians $97^{\circ} 16^{\prime}$ and $97^{\circ} 34^{\prime}$ of longitude west; the second is located between parallels $19^{\circ} 02^{\prime}$ and $19^{\circ} 16^{\prime}$ of latitude north and meridians $97^{\circ} 12^{\prime}$ and $97^{\circ} 30^{\prime}$ of longitude west. The land use destined to agriculture occupies $79 \%$; the urban zone, $3 \%$; the forest, $14 \%$; the grasslands, $3 \%$; and the shrubs, $1 \%$ (INAFED, 2010). In Tlachichuca, the land use and vegetation corresponds to agriculture $(49.53 \%)$ and urban zone $(0.57 \%)$, forest $(35.75 \%)$, grassland $(7.64 \%)$ and scrubland (4.35\%) (INEGI, 2010). 


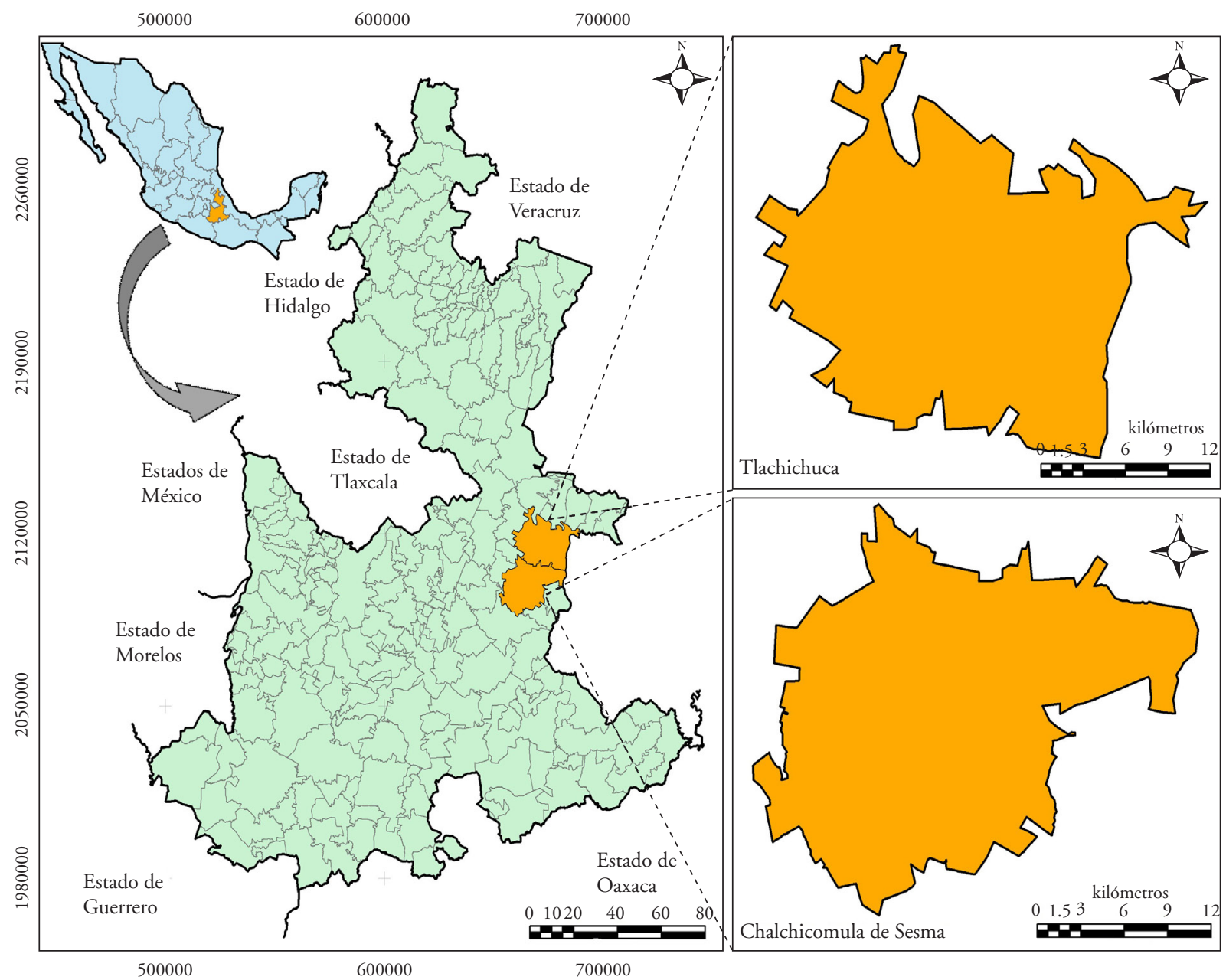

Fuente: elaboración propia, 2010. * Source: authors' elaboration, 2010.

Figura 1. Ubicación geográfica de los municipios de estudio Figure 1. Geographic location of the municipalities of study.

ocupa $79 \%$; la zona urbana, $3 \%$; el bosque, $14 \%$; los pastizales, $3 \%$; y los matorrales, $1 \%$ (INAFED, 2010). En Tlachichuca, el uso de suelo y vegetación corresponde a la agricultura (49.53\%) y zona urbana $(0.57 \%)$, bosque (35.75\%), pastizal (7.64 \%) y matorral (4.35\%) (INEGI, 2010).

La selección del sitio de estudio obedeció a que estos municipios son considerados de alto potencial productivo y tienen los mayores rendimientos de maíz en el estado de Puebla; además, tienen estaciones meteorológicas que permiten tener información de las variables climatológicas de los años seleccionados como buenos, regulares y malos que fueron identificados de acuerdo con la percepción de los productores encuestados. El instrumento para recopilar la
The selection of the study site was because these municipalities are considered of high productive potential and have the highest maize yields in the state of Puebla; in addition, they have meteorological stations that allow gaining information about climatological variables from the years selected as good, regular and bad, which were identified according to the perception of the producers surveyed. The instrument used to gather the information was the questionnaire applied to a total of 70 farmers from both municipalities. To select the producers, the main criterion used was experience of over 30 years in agricultural practices and that they cultivate their lands under rainfed conditions. These indicators allowed guaranteeing that those 
información fue el cuestionario que se aplicó a un total de 70 agricultores de ambos municipios. Para seleccionar a los agricultores se tomó como principal criterio una experiencia superior a los 30 ańos en las prácticas agrícolas y que cultivaran sus tierras bajo condiciones de temporal. Estos indicadores permitieron asegurar que los encuestados tuvieran conocimiento sobre los dichos y su cumplimiento.

Las preguntas del cuestionario estuvieron enfocadas a identificar la percepción de los agricultores con respecto a los años agrícolas buenos, regulares y malos, además de conocer el cumplimiento de siete dichos o saberes populares aplicados al clima y que se relacionan con la agricultura:

1. Las secas de marzo son lluvias en mayo o, lo que es lo mismo, "seco marzo, lluvioso mayo".

2. Calor de marzo temprano, es para el campo muy sano

3. Lluvia en abril, granos en mil

4. Agua de mayo, pan para todo el ańo

5. Si el invierno veranea, el verano invernea

6. En septiembre o seca las fuentes o se lleva los puentes

7. El cordonazo de San Francisco. Se refiere al primer frío del año; el 4 de octubre es la fecha asignada por las efemérides cristianas para festejar a Francisco de Asís.

Para interpretar la información se utilizó la estadística descriptiva; se aplicó la prueba de chi cuadrado y se realizó una regresión logística aplicada a un grupo de diferentes variables sociales, económicas y agronómicas de los productores encuestados para conocer la aceptación y no aceptación de los dichos. Para comprobar el cumplimiento de los dichos de los años identificados en las encuestas se utilizó información de la estación meteorológica ubicada en la localidad de Ciudad Serdán con clave 21026; se aplicó el programa desarrollado en Mathlab, versión 5, para obtener gráficas relacionadas con variables de temperatura mínima, máxima totales y el promedio de cinco días (pentadas) de la precipitación para tener una mejor apreciación de la intermitencia de dicha variable. Los siete dichos fueron relacionados con la marcha anual de las variables climatológicas (temperatura mínima, temperatura máxima y precipitación) para cada ańo identificado de acuerdo a la percepción de los productores. surveyed had knowledge about the proverbs and their fulfillment.

The questions from the questionnaire were focused on identifying the perception that farmers have regarding good, regular and bad agricultural years, in addition to exploring the fulfillment of seven proverbs or popular sayings applied to the weather and which are related to agriculture:

1. Dry times in March mean rains in May or, in other words, "dry March, rainy May". (Las secas de marzo son lluvias en mayo o, lo que es lo mismo, "seco marzo, lluvioso mayo".)

2. Heat in early March is quite healthy for the country. (Calor de marzo temprano, es para el campo muy sano.)

3. Rain in April, grains in the thousands. (Lluvia en abril, granos en mil.)

4. Water in May, bread for the whole year. (Agua de mayo, pan para todo el año.)

5. If Winter becomes Summer, Summer becomes Winter. (Si el invierno veranea, el verano invernea.)

6. In September either the fountains dry up or the bridges overflow. (En septiembre o seca las fuentes $o$ se lleva los puentes.)

7. El Cordonazo de San Francisco. It refers to the first cold time of the year; October 4th is the date assigned by the ephemeris to celebrate Saint Francis of Assisi.

Descriptive statistics were used to interpret the information; the square Chi test was used and a logistic regression was applied to a group of different social, economic and agronomic variables of the producers surveyed to explore the acceptance and lack of acceptance of the proverbs. To verify the fulfillment of the proverbs from the years identified in the surveys, information from the meteorological station located in Ciudad Serdán with key 21026 was used; the program developed in Mathlab, version 5 , was applied in order to obtain graphs related to variables of minimum temperature, total maximum, and average of five days (pentads) of precipitation to gain a better appreciation of the intermittence of that variable. The seven sayings were related to the annual progress of the climatological variables (minimum temperature, maximum temperature and precipitation) for each year identified according to the producers' perception. 


\section{Resultados y Discusión}

Los agricultores encuestados tienen una valiosa experiencia en las actividades agrícolas y específicamente en la producción de maíz; esto se evidenció en su promedio de edad (58.5 años) y en su experiencia trabajando en el campo (41 años). En los municipios de estudio es arraigada la siembra de este cultivo. La superficie agrícola promedio detectada fue de cuatro hectáreas, predominando el ejido (85.7 \%). Estos datos ponen de relieve que se tiene una agricultura de corte minifundista, producto de la política agrícola que ha impulsado una agricultura dual que han privilegiado al sector empresarial sobre la pequeña agricultura que representa más de $80 \%$ de las explotaciones agrícolas de Latinoamérica de acuerdo con la Organización de las Naciones Unidas para la Alimentación y la Agricultura (FAO, 2011).

Con respecto a los refranes, Pelosse (1997) menciona que el saber meteorológico popular es rural, local y está ligado a las prácticas agrícolas, a la pesca y a la navegación. En ese sentido se encontró que la totalidad de encuestados conocen los refranes que hacen referencia a la agricultura, como "Las secas de marzo son lluvias en mayo" o, lo que es lo mismo, "seco marzo, lluvioso mayo". "Calor de marzo temprano es para el campo muy sano". "Lluvia en abril, granos en mil". "Agua de mayo, pan para todo el año". "Si el invierno veranea, el verano invernea". "En septiembre o seca las fuentes o se lleva los puentes". "El cordonazo de San Francisco" se refiere al primer frío del año, el 4 de octubre. En ese sentido, Rudnev (1997) también reafirma que los refranes son locales y lo confirma con uno de los campesinos rusos que dice: "MayoJunio con agua, con hierba", "mucha nieve, mucho pan». Está estrechamente relacionado con la abundancia de pan y heno, y con el carácter específico de las condiciones climáticas locales que reflejan las singularidades folclóricas observadas en el clima.

Sobre la certidumbre de los refranes, $54.3 \%$ opinó que estos aún se cumplen; estos resultados tienen alguna similitud con los encontrados en un estudio que realizó Conde (1998) en Galicia. Aquí, 38 \% de los encuestados consideraron verdaderos a los refranes, $13.7 \%$ dijo que eran falsos, y $41.1 \%$ piensa que a veces son verdaderos. En este sentido argumentaron que los que más se cumplen fueron: "Calor en marzo temprano es para el campo muy sano" (40 \%), "Agua

\section{Results AND Discussion}

The farmers surveyed have valuable experience in agricultural activities and specifically in maize production; this is evidenced in their average age (58.5 years) and in their experience working in the countryside (41 years). Sowing this crop is something rooted in the municipalities of study. The average agricultural surface detected was four hectares, with the ejido predominating (85.7 \%). These data emphasize that there is small-scale agriculture, product of the agricultural policy that has driven a dual agriculture that the entrepreneurial sector has privileged over small-scale agriculture representing more than $80 \%$ of farms in Latin America, according to the United Nations Food and Agriculture Organization (FAO, 2011).

With regards to the proverbs, Pelosse (1997) mentions that popular meteorological knowledge is rural, local and linked to agricultural practices, fishing and navigation. In this sense it was found that the totality of those surveyed understands the proverbs that refer to agriculture, such as "Dry times in March mean rains in May", in other words, "dry March, rainy May". "Heat in early March is quite healthy for the country." "Rain in April, grains in the thousands." "Water in May, bread for the whole year." "If Winter becomes Summer, Summer becomes Winter." "In September either the fountains dry up or the bridges overflow." "El Cordonazo de San Francisco" refers to the first cold time of the year, October $4^{\text {th }}$. In that sense, Rudnev (1997) also reasserts that the proverbs are local and he confirms this with one of the Russian peasants who say: "May to June with water, with weed", "Much snow, much bread". It is closely related to the abundance of bread and hay, and with the specific character of the local climate conditions that reflect the folkloric singularities observed in the weather.

Concerning the certainty of the proverbs, $54.3 \%$ had the opinion that they are still fulfilled; these results are somewhat similar to those found in a study carried out by Conde (1998) in Galicia. Here, $38 \%$ of those surveyed considered the sayings to be true, $13.7 \%$ said they were false, and $41.1 \%$ thought that they are sometimes true. In this sense, they argued that the ones that are most often fulfilled are: "Heat in early March is quite healthy for the 
de mayo, pan para todo el año" (31.1\%), y "En septiembre o se secan las fuentes o se lleva los puentes" (28.6 \%). Los que menos se cumplieron fueron: "Las secas de marzo son lluvias en mayo" o, lo que es lo mismo, "seco marzo, lluvioso mayo" (32.9\%), "Lluvia en abril, granos en mil" (20\%), y "El cordonazo de San Francisco", 4 de octubre, festejo a Francisco de Asís, primer frío del año (17.1\%). Conde (1998) menciona que con el paso del tiempo el refranero ha sufrido transformaciones y que el cambio de costumbres hace que se comience a cuestionar su verdad.

$\mathrm{Al}$ respecto, Pelosse (1997) argumenta que la meteorología científica adquirió los medios técnicos para una verdadera previsión del tiempo, mientras que a escala local de "micro-clima" (en un radio de $10 \mathrm{Km}$.), donde intervienen los apremios orográficos y diversos factores aleatorios, las creencias populares continúan. Es importante destacar que se encontró coincidencia entre los años buenos (1980 y 2013) y los refranes que mencionaron los agricultores; entre los que más se cumplieron están: "Calor de marzo temprano, es para el campo muy sano"; "Lluvia en abril, granos en mil"; "Agua de mayo, pan para todo el ańo"; "En septiembre o seca las fuentes o se lleva los puentes" y "El cordonazo de San Francisco".

Los refranes que los agricultores dijeron que se cumplen menos se presentaron principalmente en el año malo (2011) y el año regular (1987), y fueron: "Las secas de marzo son lluvias en mayo" o, lo que es lo mismo, "seco marzo, lluvioso mayo". "Calor de marzo temprano, es para el campo muy sano". "Lluvia en abril, granos en mil". "Agua de mayo, pan para todo el año" y "Si el invierno veranea, el verano invernea" (Cuadro 1). Para conocer cuáles son los factores que se encuentran relacionados con la aceptación o no aceptación de los refranes, de acuerdo con el modelo de regresión logística aplicado a un grupo de diferentes variables sociales, económica y agronómica de los productores de maíz de los municipios de estudio, después de un proceso de selección de variables se encontró que el rendimiento, las prácticas que realizan los agricultores para mejorar la producción de maíz y el tiempo que dura la lluvia en minutos, resultaron significativas (Cuadro 2), es decir, que existe una asociación entre el rendimiento, la realización de prácticas productivas y la lluvia con la aceptación y no aceptación de los dichos.

Se plantea que los rendimientos y las prácticas productivas -fertilización y control de plagas- y la country" (40\%), "Water in May, bread for the whole year" (31.1\%), and "In September, either the fountains dry up or the bridges overflow" (28.6\%). The ones that were least fulfilled were: "Dry times in March mean rains in May" or, in other words, "dry March, rainy May" (32.9 \%), "Rain in April, grains in the thousands" (20\%), and "El Cordonazo de San Francisco", October $4^{\text {th }}$, celebrating Saint Francis of Assisi, first cold time of the year (17.1\%). Conde (1998) mentions that with passing time the collection of proverbs has suffered transformations and that the change in customs is making it so their veracity is beginning to be questioned.

In this regard, Pelosse (1997) argues that scientific meteorology acquired the technical means for true weather prediction, while popular beliefs continue at the local scale of "micro-climate" (within a radius of $10 \mathrm{~km}$ ), where orographic pressures and various random factors intervene. It is important to highlight that a coincidence was found between the good years (1980 and 2013) and the sayings that the farmers mentioned; among the ones that were fulfilled most are: "Heat in early March is quite healthy for the country"; "Rain in April, grains in the thousands"; "Water in May, bread for the whole year"; "In September, either the fountains dry up or the bridges overflow", and "El Cordonazo de San Francisco".

The proverbs that the farmers said are least fulfilled were present primarily in the bad year (2011) and the regular year (1987), and they were: "Dry times in March mean rains in May", in other words, "dry March, rainy May". "Heat in early March is quite healthy for the country". "Rain in April, grains in the thousands". "Water in May, bread for the whole year" and "If Winter becomes Summer, Summer becomes Winter" (Table 1). To understand what are the factors related to the acceptance or lack of acceptance of the sayings, according to the logistic regression model applied to a group of different social, economic and agronomic variables of maize producers in the municipalities of study, after a process of variable selection it was found that the yield, the practices that the farmers carry out to improve maize production, and the time that rainfall lasts in minutes, were significant (Table 2 ); that is, that there is an association between the yield, performing productive practices, and rainfall with the acceptance or lack of acceptance of the proverbs. 
Cuadro 1. Dichos identificados y su relación con los rendimientos en la región de estudio. Table 1. Proverbs identified and their relationship with the yields of the study region.

\begin{tabular}{|c|c|c|c|c|}
\hline \multirow[b]{2}{*}{ Tipo de refrán } & \multicolumn{4}{|c|}{ Comportamiento de los ańos y estimación de rendimientos } \\
\hline & $\begin{array}{c}1980 \\
\text { (bueno) }\end{array}$ & $\begin{array}{c}1987 \\
\text { (Regular) }\end{array}$ & $\begin{array}{c}2011 \\
(\text { Malo })\end{array}$ & $\begin{array}{c}2013 \\
\text { (bueno) }\end{array}$ \\
\hline $\begin{array}{l}\text { Las secas de marzo son lluvias en mayo o, lo que es lo mismo, "seco } \\
\text { marzo, lluvioso mayo". }\end{array}$ & & $\mathrm{x}$ & $\mathrm{x}$ & $\mathrm{x}$ \\
\hline Calor de marzo temprano es para el campo muy sano & & $\mathrm{x}$ & $\mathrm{x}$ & \\
\hline Lluvia en abril, granos en mil & & $\mathrm{x}$ & $\mathrm{x}$ & \\
\hline Agua de mayo, pan para todo el ańo & & $\mathrm{x}$ & $\mathrm{x}$ & \\
\hline Si el invierno veranea, el verano invernea & & $\mathrm{x}$ & $\mathrm{x}$ & $\mathrm{x}$ \\
\hline En septiembre o seca las fuentes o se lleva los puentes & & & & \\
\hline $\begin{array}{l}\text { El cordonazo de San Francisco. Se refiere al primer frío del año, el } 4 \\
\text { de octubre, fecha asignada por las efemérides cristianas para festejar a } \\
\text { Francisco de Asís. }\end{array}$ & & & $\mathrm{x}$ & \\
\hline Grado de cumplimiento & $7 / 7$ & $2 / 7$ & $2 / 7$ & $5 / 7$ \\
\hline
\end{tabular}

Fuente: elaboración propia a partir de datos de encuesta, 2014. Source: authors' elaboration from data from the survey, 2014.

duración de las lluvias tienen efectos directos e indirectos sobre los agricultores en la aceptación y no aceptación de los dichos. Estos resultados concuerdan con la opinión de los encuestados, quienes en promedio comentaron que hace 9.7 años han observado que el clima está cambiando y dieron como argumento que en la región ya no llueve como antes y que son más frecuentes las sequías y las heladas. Este resultado concuerda con la investigación de Ramírez (2013), que encontró que lo que más afecta al campo es la frecuencia de los siniestros, como las sequías, heladas e impacto en la superficie afectada y el efecto en los rendimientos, aumentando la vulnerabilidad en la producción de maíz de temporal. Los agricultores que opinaron que los dichos aún se cumplen y los que dijeron que ya no tuvieron la misma opinión estadísticamente $\left(c^{2}=0.564 ; p=0.754\right)$. Con respecto a los principales problemas que tienen en las actividades agrícolas mencionaron los precios de sus productos del maíz (34.3\%), el clima (35.7\%) y los costos del fertilizante (30.0\%). En ese sentido, los agricultores no solo tienen que luchar contra la
It is suggested that the yields and the productive practices -fertilization and pest control- and the duration of rainfall have direct and indirect effects on the farmers in terms of the acceptance and lack of acceptance of the proverbs. These results coincide with the opinion of those surveyed, who in average mentioned that since 9.7 years ago they have observed that the climate is changing and they gave as argument that it does not rain as before in the region and that drought and frosts are more frequent. This result agrees with the research by Ramírez (2013), who found that the factor that affects most the countryside is the frequency of disasters, such as droughts, frosts and impact on the surface affected and effect on the yields, increasing the vulnerability of the rainfed maize production. The farmers had the opinion that proverbs are still being fulfilled and the ones who said that they are not anymore had the same opinion statistically $\left(c^{2}=0.564 ; p=0.754\right)$. Regarding the main problems that agricultural activities have, they mentioned the prices of their maize products $(34.3 \%)$, climate $(35.7 \%)$, and

Cuadro 2. Estimadores del modelo de regresión logística con el método de selección por pasos hacia adelante (Wald). Table 2. Estimators of the logistic regression model with the method of selection through steps forward (Wald).

\begin{tabular}{lccrrr}
\hline Variables & B & E.T. & Wald & P & Exp(B) \\
\hline Rendimiento & 7.566 & 2.390 & 10.019 & 0.002 & 1930.863 \\
Actividad/mejorar/ producción & 1.894 & 0.847 & 5.003 & 0.025 & 6.648 \\
Tiempo duración lluvia & 1.320 & 0.558 & 5.582 & 0.018 & 3.742 \\
Constante & -28.872 & 9.294 & 9.650 & 0.002 & 0.000 \\
\hline
\end{tabular}

Fuente: Elaboración propia a partir de datos de encuesta, 2014. Source: authors' elaboration from data from the survey, 2014. 
política agrícola, sino también contra el clima. Al respecto, Juárez y Ramírez-Valverde (2013) mencionan que los agricultores ante la política agrícola a la hora de invertir en la producción de maíz son cautelosos y no invierten más de lo que consideran adecuado. $\mathrm{Al}$ analizar los siete dichos y los años de estudio (1980, 1987, 2011 y 2013) se encontró que explican en mayor o menor grado las variables del clima. Al analizar el ańo1980 -considerado como bueno-, se tiene que para el dicho "Las secas de marzo son lluvias en mayo, o bien "seco marzo, lluvioso mayo", el mes de marzo se observó ausencia de precipitación, presentándose las lluvias en mayo, durante las seis pentadas, resaltando la segunda con $36 \mathrm{~mm}$ y la quinta con 21 mm. Para "Calor de marzo temprano, es para el campo muy sano". Durante mayo se presentaron temperaturas de $27.6{ }^{\circ} \mathrm{C}$ y con $30.2^{\circ} \mathrm{C}$ en las pentadas 2 y 7. Para "Lluvia en abril, granos en mil" se calcularon seis pentadas de abril; cuatro contribuyeron con lluvia, dos al inicio $(4 \mathrm{~mm}$ y $12 \mathrm{~mm}$ ) y dos al final $(5$ $\mathrm{mm}$ y $4 \mathrm{~mm}$ ), con un total de $16 \mathrm{~mm}$., siendo una distribución de lluvia adecuada para fecha de siembra. Para el dicho "Agua de mayo, pan para todo el año", el mes de mayo tuvo una precipitación de más de $120 \mathrm{~mm}$. Para "Si el invierno veranea, el verano invernea", en el verano, Junio-Julio-Agosto, no se presentaron condiciones que mostraran horas frío/ heladas. El dicho "En septiembre o seca las fuentes o se lleva los puentes" que incluye agua, esta siempre mostró una tendencia positiva de acumulación por pentada. Como consecuencia de una canícula húmeda, de tener una "capacidad de campo saturada", si se presenta lluvia ciclónica esta escurrirá con poca infiltración; entonces, toda el agua acumulada en la cuenca generará una corriente con posibilidades de "incremento de riesgos" aguas abajo. Generalmente, los productores esperan las primeras heladas a finales de Septiembre; según el dicho: "El cordonazo de San Francisco", donde que coincide con la pentada del 02 al 06 de octubre, se presentó la primera helada "agronómica”, con una temperatura mínima promedio de $3.8^{\circ} \mathrm{C}$. Para este año bueno se cumplieron los siete dichos (Figura 2).

El año de 1987 es considerado como regular para el dicho "Las secas de marzo son lluvias en mayo", mientras que en el caso de: "Agua de mayo, pan para todo el año", en la primera pentada de marzo 02-06 se observó una acumulación de lluvia de $6.5 \mathrm{~mm}$ y una precipitación total en el mes de $8.0 \mathrm{~mm}$, lo que costs of the fertilizer $(30.0 \%)$. In this sense, the farmers not only have to fight against the agricultural policy, but also against the weather. In this regard, Juárez and Ramírez-Valverde (2013) mention that farmers facing the agricultural policy at the time of investing in maize production are careful and they don't invest more than what is considered adequate. When analyzing the seven proverbs and study years (1980, 1987, 2011 and 2013), it was found that they explain the climate variables to a greater or lesser degree. When analyzing the year 1980 -considered as good-it was found that for the saying, "Dry times in March mean rains in May" or, in other words, "dry March, rainy May", an absence of rain was observed during the month of March, with rainfall being present in May, during, during the six pentads, with the second one standing out with $36 \mathrm{~mm}$ and the fifth one with $21 \mathrm{~mm}$. For "Heat in early March is quite healthy for the country", during May there were temperatures of $27.6^{\circ} \mathrm{C}$ and $30.2^{\circ} \mathrm{C}$ in the pentads 2 and 7. For "Rain in April, grains in the thousands", six pentads were calculated in April; four contributed with rains, two at the beginning ( $4 \mathrm{~mm}$ and $12 \mathrm{~mm}$ ) and two at the end $(5 \mathrm{~mm}$ and $4 \mathrm{~mm}$ ), with a total of $16 \mathrm{~mm}$, with the rain distribution being adequate for a sowing date. For the saying "Water in May, bread for the whole year", the month of May had a precipitation of more than $120 \mathrm{~mm}$. For "If Winter becomes Summer, Summer becomes Winter", in the summer, June-July-August, there were not conditions that showed hours of cold / frosts. The saying "In September, either the fountains dry up or the bridges overflow", which includes water, there was always a positive accumulation trend per pentad. As consequence of humid midsummer heat, of having "saturated field capacity", if there is cyclonic rainfall it will drain with scarce infiltration; then, all the water accumulated in the watershed will generate a current of possibilities of "risk increase" downstream. Generally, the producers expect the first frosts at the end of September; according to the proverb, "El Cordonazo de San Francisco", which coincides with the pentad from October $2^{\text {nd }}$ to $6^{\text {th }}$, the first "agronomic" frost was present, with a minimum average temperature of $3.8^{\circ} \mathrm{C}$. For this good year the seven proverbs were fulfilled (Figure 2).

The year of 1987 is considered as regular for the saying "Dry times in March mean rains in May", while in the case of: "Water in May, bread for the 


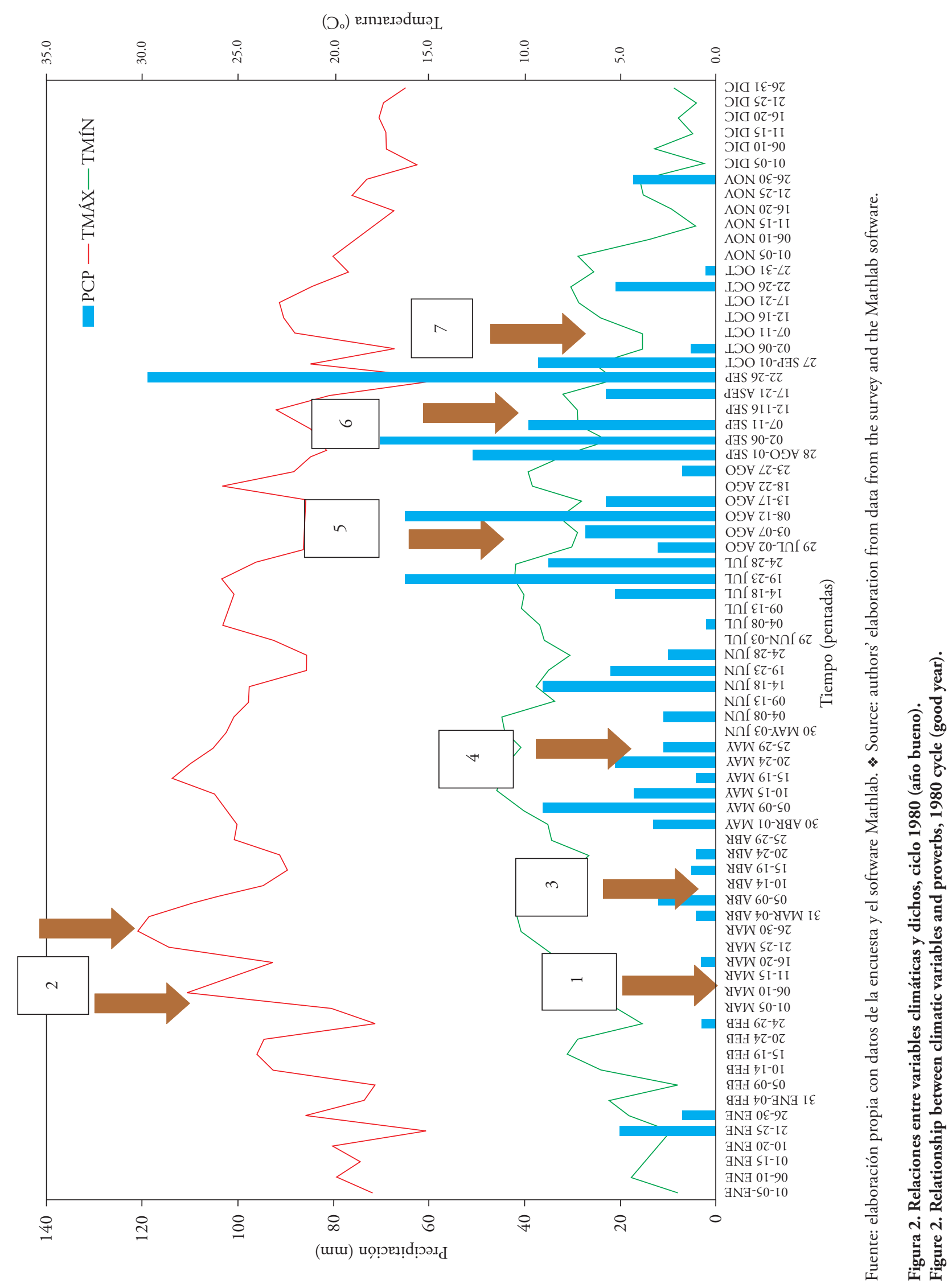


representa escasez de lluvia. De acuerdo con el dicho se esperaba que en mayo se presentara lluvia; sin embargo, no fue así. Durante mayo llovió un total de 16 $\mathrm{mm}$. Resaltando la segunda y la tercera pentada con 8.5 y $5.5 \mathrm{~mm}$. El dicho "Calor de marzo temprano es para el campo muy sano" no se cumplió, aunque se presentaron dos máximos de temperaturas en la primera fecha de 02-06 de marzo, con una temperatura de 19.1 y quinta pentada con $21.5^{\circ} \mathrm{C}$. En el caso de "Lluvia en abril, granos en mil", este no se cumplió ya que hubo escasez de lluvia durante el mes de abril y en la sexta pentada se observó un incremento de $7.5 \mathrm{~mm}$, con una precipitación total en el mes de 12 $\mathrm{mm}$. Para "Si el invierno veranea, el verano invernea", en el verano Junio-Julio-Agosto no se presentaron condiciones que mostraran horas frio/heladas. Con respecto al dicho que incluye agua, hubo una tendencia positiva de acumulación por pentada. Sin embargo, a partir de la primera pentada del mes de agosto se presentó una disminución de lluvia de 17 $\mathrm{mm}$, con un total de $29.5 \mathrm{~mm}$. Para "En septiembre o seca las fuentes o se lleva los puentes" se presentó otro evento, que es la canícula o suspensión parcial de la lluvia en pleno verano; en este caso se puede catalogar como una "Canícula seca" y durante el mes de septiembre hubo escasez de lluvia $-80.5 \mathrm{~mm}$-. En el caso del dicho "El cordonazo de San Francisco", coincide en la pentada del 03 al 07 de octubre; se presentó la primer helada "agronómica" con una temperatura mínima de $0.2^{\circ} \mathrm{C}$. Para este año se cumplieron dos dichos de siete (Figura 3).

En 2011 (año malo), en lo que respecta a los dichos "Las secas de marzo son lluvias en mayo" y "Agua de mayo, pan para todo el año", se presentó escasez de lluvia, aunque existió un incremento en la tercera y sexta pentada de 7.5 y $1.5 \mathrm{~mm}$, respectivamente, con un total de $9 \mathrm{~mm}$. En mayo resaltó la fecha del 11-15 de marzo, con $45.5 \mathrm{~mm}$ y un total de 58.5 $\mathrm{mm}$. Para el dicho "Calor de marzo temprano es para el campo muy sano" se presentó un valor extremo en las temperaturas máximas donde resalta la sexta pentada de marzo del 27-31 de marzo, con un valor de $28.6^{\circ} \mathrm{C}$. El dicho "Lluvia en abril, granos en mil" no se cumplió y la producción no fue la esperada, ya que se observó una distribución uniforme, pero la precipitación no fue relevante. La contribución de la lluvia durante el mes de abril se presentó con un incremento en la cuarta pentada del $16-20$ con $23.5 \mathrm{~mm}$. Para el dicho "Si el invierno veranea, el verano invernea", whole year", rain accumulation of $6.5 \mathrm{~mm}$ was observed in the first pentad of March 2 to 6, and total precipitation in the month of $8.0 \mathrm{~mm}$, which represents rain scarcity. According to the saying, it was expected for there to be rain in May; however, it was not so. During May it rained a total of $16 \mathrm{~mm}$, with the second and third pentad standing out, with 8.5 and $5.5 \mathrm{~mm}$. The saying "Heat in early March is quite healthy for the country" was not fulfilled, although two maximum temperatures were present during the first date of March 2-6, with a temperature of 19.1 and the fifth pentad with $21.5^{\circ} \mathrm{C}$. In the case of "Rain in April, grains in the thousands", it was not fulfilled since there was no rain scarcity during the month of April and an increase of $7.5 \mathrm{~mm}$ was observed during the sixth pentad, with total precipitation in the month of $12 \mathrm{~mm}$. For "If Winter becomes Summer, Summer becomes Winter", in the summer of June-July-August there were not conditions that showed hours of cold/frosts. With regards to the saying that includes water, there was a positive trend of accumulation per pentad. However, starting from the first pentad of the month of August, a decrease in rainfall of $17 \mathrm{~mm}$ was present, with a total of 29.5 $\mathrm{mm}$. For "In September, either the fountains dry up or the bridges overflow", another event was present, which is the midsummer heat or partial suspension of rainfall in the midst of summer; in this case it can be catalogued as "Dry midsummer heat" and during the month of September there was scarcity of rainfall- $80.5 \mathrm{~mm}$. In the case of the proverb "El Cordonazo de San Francisco", it coincides with the pentad from October 3 to 7; the first "agronomic" frost was present with a minimum temperature of $0.2^{\circ} \mathrm{C}$. For this year, two of the seven proverbs were fulfilled (Figure 3).

In 2011 (bad year), concerning the proverbs "Dry times in March mean rains in May" and "May water, bread for the whole year", rainfall scarcity was present, although there was an increase in the third and sixth pentad of 7.5 and $1.5 \mathrm{~mm}$, respectively, with a total of $9 \mathrm{~mm}$. In May the date of March 1115 stood out, with $45.5 \mathrm{~mm}$ and a total of $58.5 \mathrm{~mm}$. For the saying "Heat in early March is quite healthy for the country", an extreme value was present in the maximum temperatures where the sixth pentad on March 27-31 stands out, with a value of $28.6{ }^{\circ} \mathrm{C}$. The proverb "Rain in April, grains in the thousands" was not fulfilled and the production was not what 




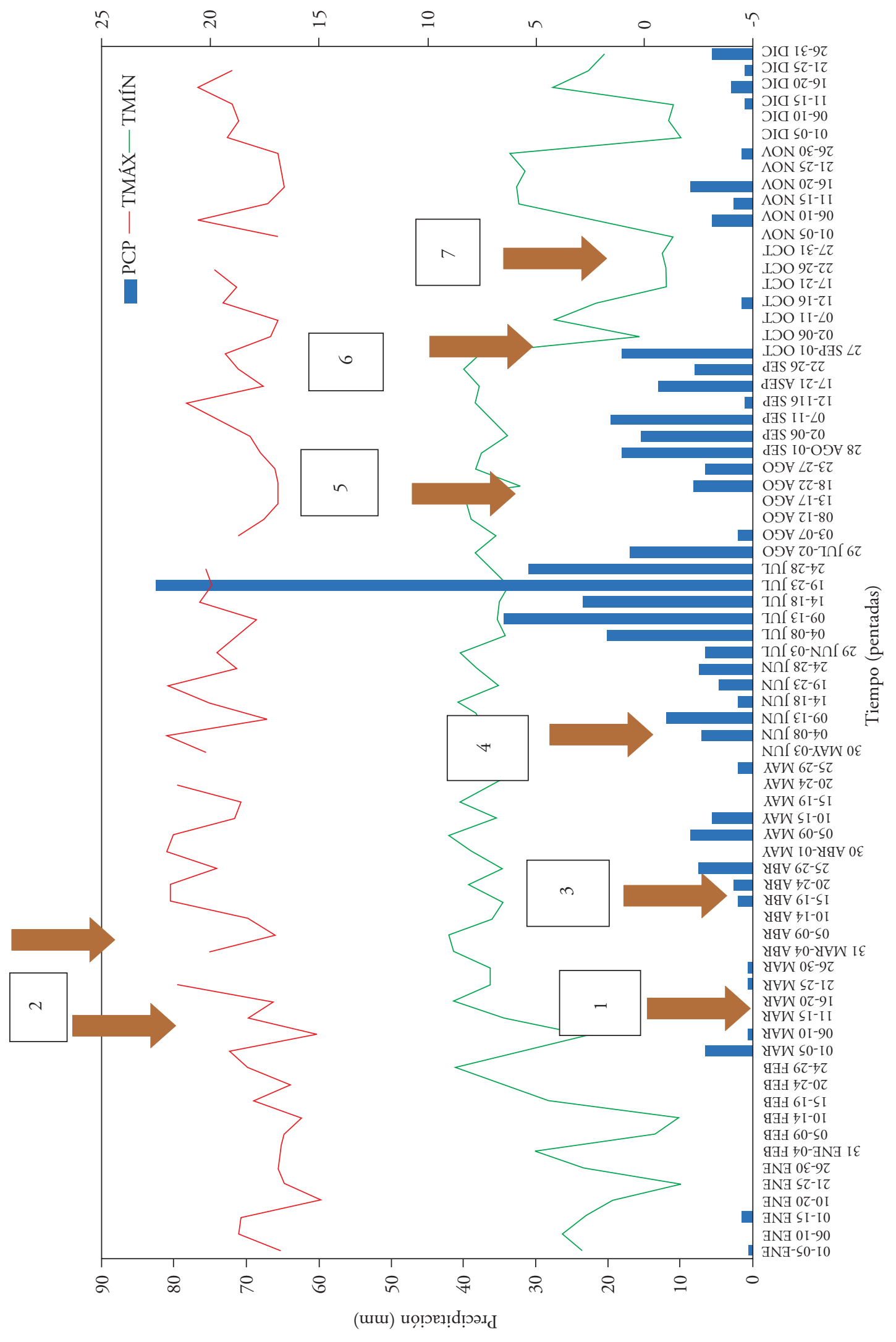


en Junio-Julio-Agosto no se presentaron condiciones que mostraran horas frío/heladas. Se puede observar que durante julio se presentó una disminución de la precipitación en la fecha del 15-19 y, aunque en la sexta pentada la lluvia se incrementó a $26.5 \mathrm{~mm}$, se consideró como una canícula seca. Durante agosto también existió ausencia de lluvia en la primera y segunda pentada, con un total de lluvia de $42.5 \mathrm{~mm}$. En el caso del dicho "En septiembre o seca las fuentes o se lleva los puentes", en septiembre la máxima precipitación fue del 29 de agosto al 02 de septiembre con $53 \mathrm{~mm}$ y un total de $71 \mathrm{~mm}$ en el mes, lo cual está relacionado con el año de mala producción para el cultivo del maíz. Para el dicho "El cordonazo de San Francisco" los productores esperan las primeras heladas a finales de septiembre; sin embargo, en este caso se presentaron dos heladas agronómicas en la tercera y quinta pentada, es decir, del 8-12 y del 1822 de septiembre de $4.8^{\circ} \mathrm{C}$ y $5.8^{\circ} \mathrm{C}$, respectivamente. En nuestro caso no coincide, aunque se muestra una helada meteorológica en la pentada seis del 2327 de octubre de $-0.2^{\circ} \mathrm{C}$. En este año se cumplieron dos dichos de siete (Figura 4).

Para el año 2013 (año bueno), en cuanto a los dichos "Las secas de marzo son lluvias en mayo" y "Agua de mayo, pan para todo el año", la precipitación total de marzo fue de $3.5 \mathrm{~mm}$, valor que representó lluvia escasa. La que se esperaba en mayo únicamente contribuyó en la cuarta y quinta penta$\mathrm{da}$, sumando un total de $18 \mathrm{~mm}$. Para el de "Calor de marzo temprano, es para el campo muy sano" se presentaron dos valores extremos en las temperaturas máximas; la primera del 25 de marzo al 01 de abril de $25.2^{\circ} \mathrm{C}$ y la segunda del $07-11$ de marzo de $25^{\circ} \mathrm{C}$. Aunque ambas temperaturas están dentro del promedio del sitio de estudio, este sí se cumplió debido a que correspondió a un año de buen rendimiento para el maíz. Para el de "Lluvia en abril, granos en mil" se mostró la distribución de la precipitación con excepción de la tercera pentada, resaltando la quinta del 21-25 de abril con $21.5 \mathrm{~mm}$ y la sexta del 2630 de abril con $18 \mathrm{~mm}$, con un total de $53.0 \mathrm{~mm}$. Con ello, se cumplió el dicho, aunque hubo escasez en las primeras tres pentadas. Para "Si el invierno veranea, el verano invernea”, en Junio-Julio-Agosto no se presentaron condiciones que mostraran horas frío/ heladas, aunque se mostró el valor de la temperatura mínima del $05-09$ de junio de $7.6{ }^{\circ} \mathrm{C}$ y máxima de $25.6^{\circ} \mathrm{C}$. Para "En septiembre o seca las fuentes o se was expected, since a uniform distribution was observed, but the precipitation was not relevant. The contribution of rainfall during the month of April was present with an increase in the fourth pentad of 16-20, with $23.5 \mathrm{~mm}$. For the proverb "If Winter becomes Summer, Summer becomes Winter", in June-July-August there are no conditions that showed hours of cold/frosts. It can be observed that during July there was a decrease of precipitation in the date of 15-19, and although during the sixth pentad the rainfall increased to $26.5 \mathrm{~mm}$, it was considered as a dry midsummer heat. During August there was also absence of rain in the first and second pentad, with a total rainfall of $42.5 \mathrm{~mm}$. In the case of the proverb "In September, either the fountains dry up or the bridges overflow", in September the maximum precipitation was August $29^{\text {th }}$ to September $2^{\text {nd }}$ with $53 \mathrm{~mm}$ and a total of $71 \mathrm{~mm}$ in the month, which is related to the year of bad production for maize cultivation. For the proverb "El Cordonazo de San Francisco", the producers expect the first frosts at the end of September; however, in this case two agronomic frosts were present in the third and fifth pentad, that is, on September 8-12 and 18-22 of $4.8^{\circ} \mathrm{C}$ and $5.8^{\circ} \mathrm{C}$, respectively. In our case it does not coincide, although a meteorological frost of $-0.2^{\circ} \mathrm{C}$ was observed in the sixth pentad, on October 23-27. In this year two of seven were fulfilled (Figure 4).

For the year 2013 (good year), in terms of the proverbs "Dry times in March mean rains in May" and "Water in May, bread for the whole year", the total precipitation in March was $3.5 \mathrm{~mm}$, value that represented scarce rainfall. What was expected in May only contributed in the fourth and fifth pentad, summing a total of $18 \mathrm{~mm}$. For "Heat in early March is quite healthy for the country", two extreme values in the maximum temperatures were present; the first one from March $25^{\text {th }}$ to April $1^{\text {st }}$ of $25.2^{\circ} \mathrm{C}$ and the second in March 7-11 of $25^{\circ} \mathrm{C}$. Although both temperatures are within the average of the study site, it was fulfilled because it corresponded to a good year in maize yield. For "Rain in April, grains in the thousands" the distribution of precipitation was shown, with exception of the third pentad, highlighting the fifth one on April 21-25 with 21.5 $\mathrm{mm}$ and the sixth on April 26-30 with $18 \mathrm{~mm}$, with a total of $53.0 \mathrm{~mm}$. With this, the proverb was fulfilled, although there was scarcity in the first three pentads. For "If Winter becomes Summer, Summer 


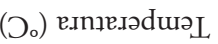

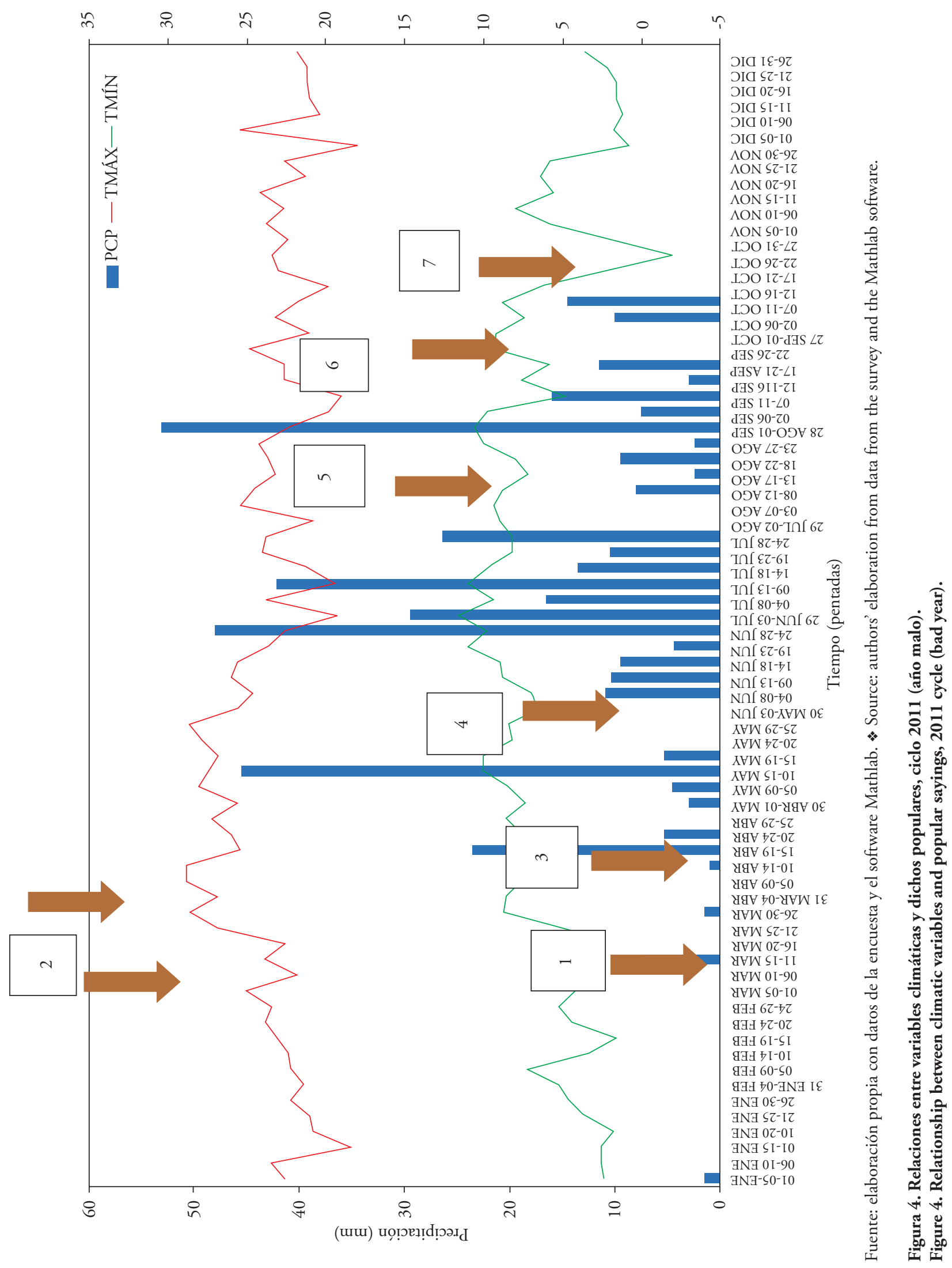


lleva los puentes", como consecuencia de una canícula húmeda resaltó una máxima precipitación durante la quinta pentada de septiembre de $42 \mathrm{~mm}$, con un total de $125 \mathrm{~mm}$. Para el dicho "El cordonazo de San Francisco", coincidió y se mostró un descenso de la temperatura del 28 de septiembre al 02 de octubre de $5^{\circ} \mathrm{C}$, considerada como helada "agronómica". Así, se cumplen cinco dichos de siete (Figura 5).

\section{Conclusiones}

Existe una coincidencia parcial del conocimiento de los productores de maíz en referencia a la variabilidad natural del clima. En los años con buenos rendimientos se cumplió el mayor número de los dichos que mencionaron los encuestados, como en el caso de 1980 y 2013, a diferencia del año regular (1987) y el año malo (2011). El clima es un sistema cambiante donde la distribución de la precipitación para el sector agrícola representa una de las variables que requiere monitoreo especializado, debido a las diferentes escalas donde se presentan las lluvias. El que algunos dichos no se hayan cumplido en este trabajo se debe a eventos de mayor escala o a la interacción de más de dos procesos. Los productores de dichas comunidades afirman que en los últimos 10 años el clima es incierto y la mayoría puede no cumplirse.

Es muy importante destacar la sinergia encontrada entre el conocimiento científico y el empírico.

\section{Agradecimientos}

Los autores agradecen a los agricultores de los municipios de Chalchicomula de Sesma y Tlachichuca del Estado de Puebla, México, que participaron realizando contribuciones que se tomaron en cuenta para realizar la investigación.

\section{Literatura Citada}

Altieri, M., y C. I. Nicholls. 2000. Agroecología. Teoría y Práctica para una Agricultura Sustentable. Serie Textos Básicos para la Formación Ambiental. Programa de las Naciones Unidas para el Medio Ambiente. México, D. F., pp: 1-250

Álvarez, Xosé. 2013. Distribución geoparemiológica de refranes meteorológicos asturianos. Lletres Asturianes, Boletín Oficial de l'Academia de la Llingua Asturiana. Núm. 109, pp: 67-102.

Blanc, A. F., y J. F. Blanc. 2003. Las cabañuelas o la predicción del tiempo en el saber popular. Nimbus: Revista de Climatología, Meteorología y Paisaje. Núm. 11, pp: 151-157. becomes Winter", in June-July-August the conditions were not present that showed hours of cold /frosts, although the value of the minimum temperature in June $5-9$ of $7.6{ }^{\circ} \mathrm{C}$ and maximum of $25.6{ }^{\circ} \mathrm{C}$ was observed. For "In September, either the fountains dry up or the bridges overflow", as consequence of a humid midsummer heat highlighted a maximum precipitation during the fifth pentad in September of $42 \mathrm{~mm}$, with a total of $125 \mathrm{~mm}$. For the proverb, "El Cordonazo de San Francisco", it coincided and a decrease was seen in temperature from September $28^{\text {th }}$ to October $2^{\text {nd }}$ of $5^{\circ} \mathrm{C}$, considered as "agronomic" frost. Thus, five of the seven proverbs were fulfilled (Figure 5).

\section{Conclusions}

There is partial agreement of the knowledge of maize producers with regards to the natural variability of the climate. In years with good yields, the highest number of proverbs that those surveyed mentioned was fulfilled, as in the case of 1980 and 2013, in contrast to the regular year (1987) and the bad year (2011). The weather is a changing system where the distribution of precipitation for the agricultural sector represents one of the variables that require specialized monitoring, due to the different scales at which rainfall is present. The fact that some proverbs were not fulfilled in this study is due to events of greater scale or to the interaction of more than two processes. The producers from those communities affirm that in the last 10 years the climate is uncertain and most cannot be fulfilled.

It is very important to highlight the synergy found between scientific and empirical knowledge.

-End of the English version -

Claverías, R. 2000. Conocimientos de los campesinos andinos sobre los predictores climáticos: elementos para su verificación. Trabajo expuesto en el Seminario-Taller organizado por Proyecto NOAA (Missouri). Chucuito-Puno.

Conde, Germán. 1998. La verdad en el refranero: los refranes meteorológicos gallegos. Paremia. Núm. 7, pp: 61 - 68.

De Pedraza, L. G. 2014. Divulgación:» Mitología de la Meteorología»;» Breve historia de la Meteorología»;» Los inciertos refranes agometeorológicos»;» Marcha periódica de los elementos meteorológicos»; y» El verano y su meteorología en Espańa». Tiempo y Clima, 3(11). 


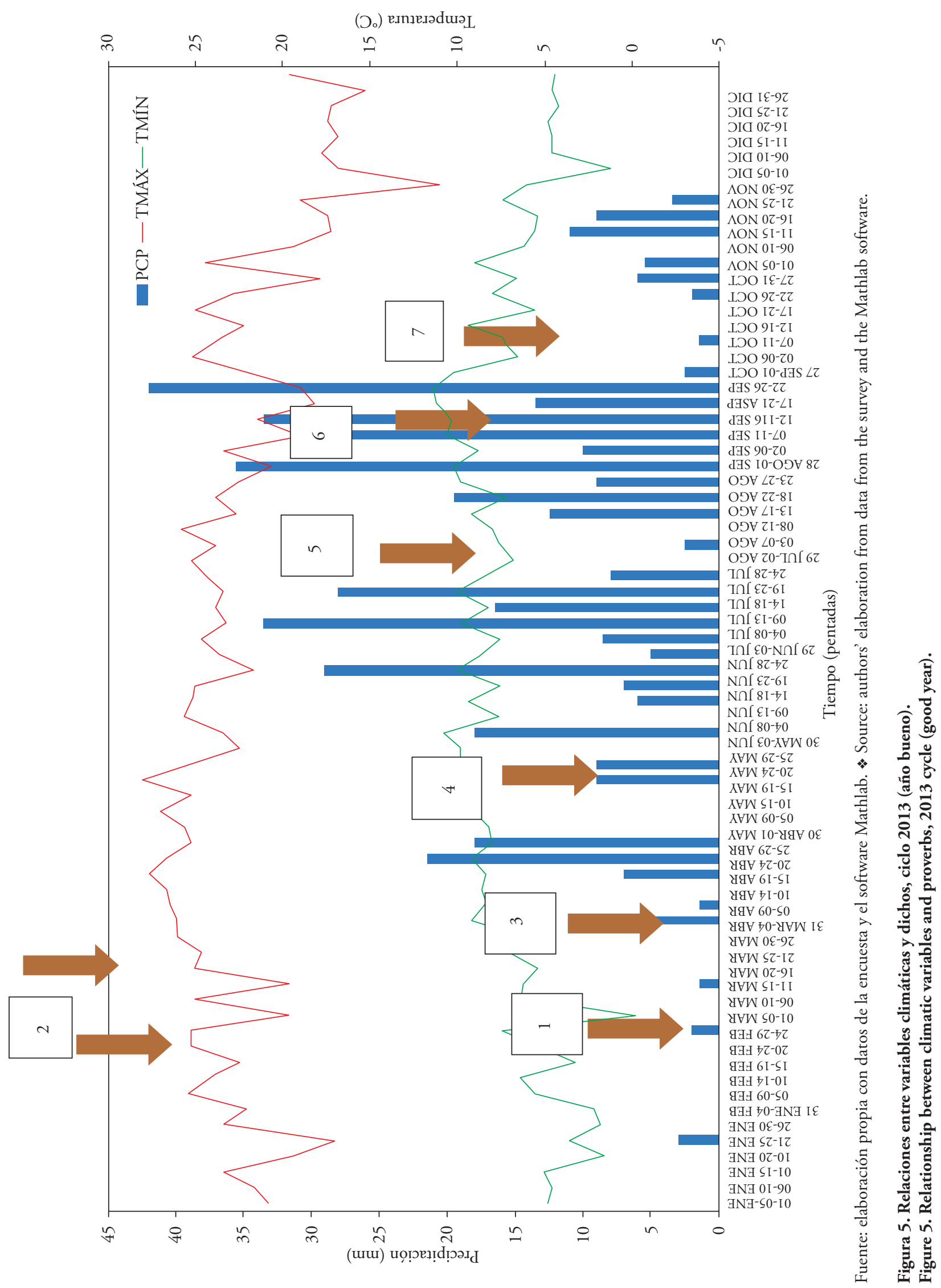


FAO (Organización de las Naciones Unidas para la Alimentación y la Agricultura) 2011. Agricultura familiar en América Latina y el Caribe. 2012 -2015., p: 40.

Fernández de Arróyabe, P. 1999. Evaluación del valor científico de los refranes como fuentes indirectas de información climática. Lurralde: investigación y espacio (22) pp: 323-338.

Gaite, M. J. M. 2011. Enseñar y aprender Geografía a partir de distintos lenguajes. Una experiencia de trabajo por proyectos para estudiar el clima de España a partir de los refranes. Anales de Geografía. Vol. 31. Núm. 1, pp: 107-123.

Gallego, B.A. 2011. Algunos aspectos de la impugnación de los refranes. Paremia, 20, pp.111-120.

Gargallo-Gil, J. E., A., Torres, y V. Franco. 2008. Líneas metodológicas de BADARE (Base de datos sobre refranes del calendario y meteorológicos en la Romania). Disponible en http:/www.divaportal.org/smash/get/diva2:382859/FULLTEXT01.pdf (consultado en febrero 2015).

González Galo. 2015. Despliegue de matices expresivos en la sabiduría popular y buen humor en la fraseología ecuatoriana. Paremia, 24, pp: 157-166.

González, Virginia 2008. Saberes campesinos y agricultura como forma de vida. Universidad Autónoma Chapingo. p: 177.

INAFED (Instituto para el Federalismo y el Desarrollo Municipal). 2010 Enciclopedia de Los Municipios y Delegaciones de México. Estado de Puebla. Disponible en http://www. inafed.gob.mx/work/enciclopedia/EMM21 puebla/index. html. (consultado en octubre 2015).

INEGI (Instituto Nacional de Estadística, Geografía e Informática). 2010. Compendio de información geográfica municipal de los Estados Unidos Mexicanos.

Juárez, Alicia. 2010. El oficio de observar y controlar el tiempo: los especialistas meteorológicos en el altiplano central. Un estudio sistemático y comparativo. Tesis de doctorado en Antropología, Universidad Nacional Autónoma de México, Facultad de Filosofía y Letras. Instituto de Investigaciones Antropológicas, 305 p.

Juárez, J. P., y B. Ramírez B. 2013. Adopción de tecnología y rendimiento en el cultivo del maíz en una región campesina del estado de Puebla. Regiones y Desarrollo Sustentable. Núm. 13 - 14, pp: $137-151$.

Kanno, H., T. Sakurai, H. Shinjo, H. Miyazaki, Y. Ishimoto, T. Saeki, y M. Chiboola, 2013. Indigenous climate information and modern meteorological records in Sinazongwe District, Southern Province, Zambia. Japan Agricultural Research Quarterly: JARQ, 47(2), pp: 191-201.

Knight, C. G. 1980. Ethnoscience and the African Farmer: Rationale and Strategy. In: D. Brokenshaw et al. (eds), Indigenous Knowledge Systems and Development, University Press of America, Lanham, MD, pp: 203-229.
Magaña, A. 2008. Conocimiento y estrategias campesinas en el manejo de los recursos naturales. Ra Ximhai, 4(2), pp: 183213.

Marrón, María. 2011. Enseñar y aprender Geografía a partir de distintos lenguajes. Una experiencia de trabajo por proyectos para estudiar el clima de Espańa a partir de los refranes. Anales de Geografía. Vol. 31. Núm. 1, pp: 107-123.

Mesa, S., A. B. Delgado, y E. Blanco. 1997. Ritos de lluvia y predicción del tiempo en la España Mediterránea. In: Antropología del clima en el mundo hispanoamericano. Tomo I. Goloubinoff, Marina, Katz, Esther y Lammel, Anna María (eds) Ediciones, ABYA-YALA, Colección Biblioteca ABYAYALA. Núm. 49, pp: $93-126$.

Molina, J. C. R. 2014. Percepciones del tiempo climático en las poblaciones campesinas de Contramaestre, Santiago de Cuba. Batey: Revista Cubana de Antropología sociocultural, 6(6), pp: 98-109.

Oliviusson Sofía. 2010. La comprensión de refranes en estudiantes de español como lengua extranjera. Stokholm University 14.

Pelosse, V.1997. Entre conocimientos populares y observación meteorológica científica al final del siglo XIX. In: Antropología del clima en el mundo hispanoamericano, Tomo I (Goloubinoff, M., Katz, E. y Lammel, A., editores. Quito Ecuador: Abya-Yala. pp: 35-47.

Ramírez, M. 2013. Política agrícola y helada en el medio rural. Caso de los productores de maíz en Tlachichuca, Puebla. Tesis de Maestría en Ciencias en Estrategias para el Desarrollo Agrícola Regional, Colegio de Postgraduados, Campus Puebla, p: 90.

Rodríguez, Rosa, Benito Águeda, y Adelaida Portela. 2004. Meteorología y Climatología. Semana de la Ciencia y la Tecnología. Fundación Española Para La Ciencia Y La Tecnología, p: 141.

Rúa, Francisco. 2013. La meteorología en el refranero. Aller Argutorio. Núm. 30, pp: 37- 42.

Rudnev, Vyacheslav 1997. Ethno-meteorology: a modern view about folk signs. In: Antropologia del clima en el mundo hispanoamericano. Tomo I. Goloubinoff, Marina, Katz, Esther y Lammel, Annamaria. (eds) Ed. ABYA-YALA, Colección. Núm. 49, pp: $27-33$.

Sevilla J. Muńoz, y Cantera Ortíz. 2002. Pocas palabras bastan: vida e interculturalidad del refrán. Salamanca: Diputación de Salamanca-Centro de Cultura Tradicional.

Sevilla M. J. y A. C. A Crida., 2013. Paremias de origen anónimo y uso preferentemente popular las paremias y su clasificación1, Paremia, 22, pp: 105-114.

Torres, Juan y José Valdivia. 2012. El clima y los conocimientos tradicionales en la región andina, Climas encontrados. Recopilación y análisis de la bibliografía temática existente. Primera aproximación. SP ITDG - UNALM, p: 68. 